\title{
Legal Consequences of Bankruptcy Towards Legal Position of Waqf Assets on Foundation
}

\author{
Sbong Sinarok Martin ${ }^{1}$ \\ ${ }^{1}$ Faculty of Law, Universitas Indonesia, Indonesia \\ sbong.sinarok@ui.ac.id
}

\begin{abstract}
Introduction to the Problem: Based on Law No. 37 of 2004 on the Bankruptcy and Payment Suspension, the consequence of Bankruptcy decisions cover the total wealth of the Bankrupt Debtors at the time of the bankruptcy declaration together with that which they acquire during the bankruptcy. According to the Bankruptcy Act, there is no explicit limitation about the bankrupt assets, which raises the ambiguity and contradiction towards the Law No. 41 of 2004 on Waqf and Law No. 28 of 2004 on the amendment of Law No. 16 of 2001 on Foundations in determining the status of waqf assets as the one of Foundation's wealth.
\end{abstract}

Purpose/Objective Study: This research aims to determine waqf assets' status on the bankrupt foundation and manage waqf assets in Indonesia's bankruptcy proceedings.

Design/Methodology/Approach: This type of research is normative legal research. The study employed secondary data from the literature review and analyzed it through the statute and conceptual approaches.

Findings: This research shows that applying the laws and implementing bankruptcy proceedings should consider other laws, which means waqf assets that the foundation manages. The waqf law overrides the bankruptcy law that is affirmed on foundation law. The bankrupt foundation's waqf assets will hand over to others' foundations or legal entities that have the same purposes.

Paper Type: Research Article.

Keywords: Bankruptcy; Waqf; Foundation; Assets

\section{Introduction}

Asset or property is goods (money and so on) that become wealth, someone's property, tangible and intangible assets that are valuable and legally owned by the company. According to Article 499 of the Indonesian Civil Code, objects are each item (goods) and each right that the right of ownership can control. Whereas what is meant by objects in the sense of law is everything that can be a legal object and goods that can be the property and rights of every person or legal subject (material rights) protected by the law. It means that material rights give direct power over a right that everyone can maintain. In other words, material rights are absolute rights that give direct authority over an object that everyone can hold and have an inherent nature. In this matter, legal subjects that possess material rights have the authority to control 


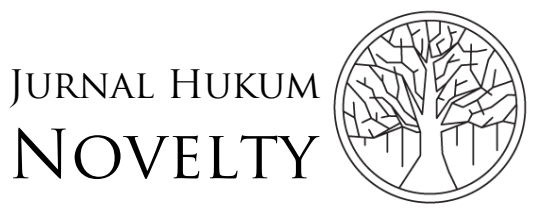

Volume 12, Issue 01, 2021, pp. 45-53

and enjoy the object's values, benefits, or materials through renting, selling, exploring, or conducting endowment (Waqf).

Waqf is legal acts conducted by wāqif to separate and or hand over some of their assets or property to be used forever or for a certain period according to waqf interests and objectivities for worship or general welfare based on Sharia. Additionally, based on Islamic law principles according to the school of Imam Abu Hanifa and Imam Maliki, the waqf objects that are endowed (donated) are their benefits. It is in line with what the Prophet said, "habasta așlaha watașaddaq bihā," (hold the original and grant its advantages). Legal actions carried out by wāqif are called the Waqf Pledge (i.e., Ikrar Wakaf) (Santoso, 2014). Wãqif here means the person who endorses his property to Nāzir. Nāzir is the party that receives waqf property from wāqif to be managed and developed according to its designation (Nurhidayani, 2017). Nāzir can include individuals, organizations, and legal entities.

Regarding Waqf objects, in Indonesia, there is an expansion of meaning. Initially, it was limited to the land, which was categorized as immovable property. However, Law No. 41 of 2004 allows waqf with movable and immovable assets. The categories described in the law include immovable objects such as land, buildings, or parts of facilities that include the land, plants, or other entities related to land, property rights to apartment units, or other immovable objects under Sharia and the Law (Nurhidayani, 2017). In contrast, on Movable Objects, the waqf can be seen as money, precious metals, securities, vehicles, items with intellectual property rights, rental rights, and movable objects according to Sharia and law, including manuscripts, holy books, books (Hazami, 2016).

Legal entities suitable to manage waqf assets are foundations (rechtpersoon), which is according to the purposes and function of the non-profit-oriented foundation (Simamora, 2012). As a legal subject, the foundation has a legal capacity to conduct legal action and participate in making an obligation (entering into an agreement that can cause a legal responsibility). In performing its functions, the foundation can conduct business activities to support its aims and objectives by establishing a business entity and or participating in it. Law No. 16 of 2001 on Foundation, article 3 (1), explains that the foundation is not used as a business place and cannot conduct business activities directly. The foundation must go through an established-business entity or through another business entity where the foundation includes its wealth.

In other words, foundation as the legal subject has a legal capacity and legal responsibility to perform the obligations and rights or become the part of an agreement. In a negative aspect, the foundation could also become one of the parties that mislead the contract due to the failure to fulfill the performance (Murni \& Gani, 2020). As we know for sure, the foundation could be in a peak season and someday falls into bankruptcy. 
Based on Law No. 37 of 2004 on Bankruptcy and Payment Suspension, bankruptcy occurs when the debtors have two or more Creditors and could not pay in full at least one debt. Also, according to this law, there is no limitation of bankruptcy assets of the bankrupt debtor (Wijayanta, 2014). There are two bankruptcy principles: paritas creditorium and pari passu prorate parte in line with article 1131 and 1132 Indonesian Civil Code. It means that all parties and their assets bear all material debts (movable and immovable) to guarantee the creditors (Pratama, 2014). It is obliged to pay his debt if referring to Bankruptcy Act No. 37 of 2004, specifically article 21 stating that bankrupt assets cover all the Debtor assets when the bankruptcy decision is pronounced and everything obtained during bankruptcy.

It is explained in the Foundation Act, particularly Article 26 (1) concerning wealth, that the wealth of the foundation can be obtained from donations or non-binding assistance, endowments (waqf), grants, wills, and other gains that do not conflict with the foundation's Articles of Association and or laws. It then explained in the next point in article 26 (3) that when the foundation's wealth comes from waqf, then the representative's legal provisions are applicable (applying waqflaw). Also, on Waqf Act No. 41 of 2004 and Government Regulations No. 42 of 2006 on Waqf implementation, there is no provision on waqf assets' legal status if the foundations that manage it fall into bankruptcy or filed for bankruptcy. Meanwhile, the Waqf Act explains in article 40 that waqf assets cannot be used as collateral, confiscated, sold, inherited, exchanged, or transferred in the form of other rights.

If a foundation that owns or manages the waqf assets is petitioned for bankruptcy or declared bankrupt by the court, then the waqf assets are questionable. Based on Foundation law, it is clear that waqf assets are acknowledged as sources of foundation's wealth, and if they refer to Bankruptcy law, the bankruptcy covers all the debtor's assets. The fundamental legal question is, How are the status and settlement of waqf assets managed by the foundations? Due to the confusion of Waqf, Foundation, and Bankruptcy Act provisions against each other, there is no clear and detailed explanation of the issues' settlement. The research objectivity analyzes whether the Waqf assets can become bankruptcy assets if the foundation that manages such assets is declared bankrupt and explain waqf assets' settlement during or after the bankruptcy process.

\section{Methodology}

This research is a normative legal study approached through a statutory and conceptual approach. The statutory course focuses on Indonesian Acts related to the study, and the conceptual approach uses legal conceptual or doctrine from legal scholars. The study used qualitative analysis through the collected data and elaborated in the form of description and explanation.

The data is collected from secondary sources and divided into three kinds of data: primary, secondary, and tertiary. The primary data sourced from the Acts and 
Regulations in Indonesia. The secondary one is taken from academic sources such as books, journals, articles that cover various aspects of this article's topic. The last data is referred to the legal dictionary such as Black Law Dictionary, Oxford Dictionary, and Indonesian Dictionary. Those tertiary data are used to obtain the more detailed meaning of specific legal terms.

\section{Results and Discussion}

\section{The Legal Position of Waqf assets after Bankruptcy Decision on Foundation}

\section{Bankruptcy Decision towards Foundation}

The foundation in Indonesia rapidly develops with many founding foundations as a forum or an activity that is generally had a social character to be non-commercial. Normatively, the foundation is made to give legal certainty and legal order for a great purpose in the social field, religion, and humanity. Foundation is the most suitable legal entity for actualizing the social, religious, and humane aspects. But in its development, the foundation starts to dive into commercial business activities.

Before Act No. 16 of 2001 on Foundation, the existence of this legal entity is blurred. There are no written laws on this matter, and it is only established based on people's customs. The legal acknowledgment of the foundation is referred back to the legal jurisprudence that is Indonesian Supreme Court Decision on June 27, 1973, No. 124 L/Sip/1973 about Pension Fund Foundation H.M.B. Indonesia.

Despite its social principle, the foundation is permitted to conduct business activities to support its aims and objectives by establishing a business entity or participating in a business entity. Foundation can conduct business activities to support its aims and objectives by establishing an indirect business entity or participating in a business entity where the Foundation invests its wealth. However, it should be borne in mind that permission to conduct business activities is to carry out the foundation's activities to achieve its objectives, not as a cover or deception to gain sympathy or deviating from taxes. Naturally, when the foundation is plunging into business activities, it is then collaborating with the probability of being bankrupt.

In the term of bankruptcy, Indonesian Bankruptcy Law did not distinguish between the bankruptcy debtors in the form of the legal entity (on this matters is foundation) or the individuals. In other words, the provisions will apply in general (Retnaningsih, 2017). Based on Article 1 point 3 of the Bankruptcy Law, the definition of a debtor is a person who has a debt due to an agreement whose repayment can be billed before the court. While in Article 1 point 4, the Bankruptcy Law states that a bankrupt debtor is a debtor who has been declared bankrupt with a court decision. In this case, if the debtor is a foundation, then the one who had the right to file a bankruptcy application is its creditor, who can be anyone (other legal subjects such as a person or legal entity). 
There is no specified amount of debt under the Indonesian Law that can be categorized to file a bankruptcy application. Whereas the debtor has been reprimanded (warning letter) by the creditor for fulfilling his debt obligations, but the debtor has not fulfilled his obligation (Sinaga \& Sulisrudatin, 2017). So, as long as the foundation has undeniable debt and could not pay it back to its creditor, the creditor could file the foundation's bankruptcy.

\section{Legal Position of Waqf Assets Under Indonesian Law}

The bankruptcy application or statement is filed in Commercial Court on the several District Court in Indonesia, which are only located on Medan, Jakarta, Semarang, Surabaya dan Makassar. During the bankruptcy process, after the debtor is declared bankrupt by the court, two can legally settle and manage the debtor's assets; both are the Supervisory Judges and Curator. The curator plays a vital role in resolving bankruptcy assets starting from inventorying assets, debt verification, asset sales (if not reconciled), and sharing the bankruptcy settlement proceeds. In comparison, the Supervisory Judge acts as a supervisor to observe and determine the stages in the bankruptcy procedure implemented by the parties (Sjahdeini, 2017). The procedural law applied in court on this matter is private and commercial law; if the foundation becomes the debtor, then the substantial law that applied should consider other regulations such as Foundation and Waqflaw.

If there is a declared-bankrupt foundation, then the curator will manage the Foundation assets. Appointed by the Commercial Court, the curator has the authority to carry out the duties or manage the assets from the date the bankruptcy announced, even though the bankruptcy decision is being submitted to an appeal or a judicial review as stipulated in Article 98 of the Bankruptcy Law (Arkisman, 2015). However, there is a possibility of error in managing the assets by the curator. The curator is required to provide the interests of the debtor and creditor and other third parties' interests.

According to Article 100 (1) of Bankruptcy Law, after the curator receives the appointment letter and no later than two days, the curator should record or inventory the debtor's assets classified as bankrupt assets. The recording or inventorying of bankrupt assets should be permitted by supervisory judges and conducting underhand, and it may be attended by a temporary creditor committee (Sahupala, 2016). Suppose the curator only refers to or used the Bankruptcy Law; it will mislead the inventorying and record the bankruptcy assets. It is because, based on Bankruptcy Law, bankruptcy covers all debtors' assets. There is no acknowledgment of the existence of privilege of waqf assets.

In that case, a legal scholar like Sudikno Mertokusumo has recommended the interpreting mechanism on laws or regulations through what he called systematic interpretation. In this mechanism, the law is seen by legal practitioners (in this case, the Curator and Supervisory Judge) as a whole, as one regulatory system. One rule 


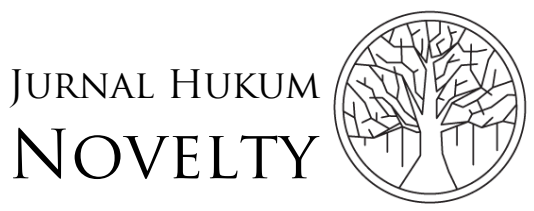

Volume 12, Issue 01, 2021, pp. 45-53

P-ISSN: 1412-6834

E-ISSN: 2550-0090

cannot be seen as a stand-alone rule but as part of a system. A rule in a set of rules justifies specific interpretations of the regulation, also in some rules, it can have the same basis of purpose or principle.

Under Indonesian law, there are three laws that relate to waqf assets' legal position if the foundation declared bankrupt: First, Law No. 41 of 2004 on waqf itself; Second, Law No.28 of 2004 on the Amendment of Law No. 16 of 2001 on Foundation as the legal subject that organizes and controls the waqf object; Third, Law No. 37 of 2004 on Bankruptcy and Suspension of Payment as the law that imposed (procedural law) towards the legal subject if the legal subject declared bankrupt.

Following the systematic interpretation, the curator should consider those three regulations. As a matter of Waqf assets on a foundation, it will be reflecting the Waqf Law as a specialist. Even though a foundation aspect is recognized and applying Bankruptcy Law, implementing this law should consider the waqf aspect, which is also reflected on Foundation Law under Article 26 (3). It then leads to a conclusion that the curator should exclude the waqf from the bankruptcy assets. This deduction is because the Waqf assets are represented as social gifts and aim for public and religion social purposes (Sutrisno, 2017). The Waqf assets' social character becomes the res extra commercium object excluded from the trade or business activities. Therefore, it can not be traded, pledged, or confiscated, although the foundation has been declared bankrupt (Hudayanti, 2017).

\section{The Responsibility of Foundation after the Foundation declared Bankrupt}

\section{The Dissolution of Foundation}

There are several reasons the foundation could be disbanded. The first reason is that the foundation's period ends and unextended anymore. Another reason is relating the foundation activities that violate the public order or morality. Being unable to settle the foundation's debt after its bankruptcy status is also why the foundation could be dissolved (Aswaratika and Anugerah, 2018). However, the bankruptcy itself did not mean the foundation will be automatically dissolved. The bankruptcy system in Indonesia only concerns the unpaid debt and unquestioning the foundation's dissolute.

Nevertheless, the existence of a foundation that does not possess anything has no reason to be maintained. Because the foundation that ever declared bankrupt might not be able to carry out activities at all to achieve its aims and objectives. Such a foundation should be disbanded; moreover, the bankrupt experience will affect the foundation's public trust if it still exists and operates (Meliala, 2013). The foundation dissolved through the application recommended by the creditor to the curator. Under Article 67 of Foundation Law, no later than seven days (from the date of the liquidation process ends), the curator should report its dissolution to the foundation's founder. In sequence, after the curator has finished the liquidation process, the curator will report the liquidation process to the founder or the supervisory judge. 
Finally, the curator then submits the liquidation's result to the Legal Entity Administration System (Rukmono, 2019). The dissolution will effectively occur since the curator's report has been received by the Minister of Justice and Human Rights in Indonesia.

\section{The Character of Waqf Management related to bankruptcy}

Indeed, the waqf assets are not included as bankrupt assets and the foundation which bankruptcy-declared has potentially disbanded. The main issue will happen to the foundation's waqf assets if this legal entity has been dissolved due to its bankruptcy status (Hafiidh \& Adjie, 2011).

The waqfs purposes have linked with the foundation's objectives in its social meaning. The aims are represented into three characteristics: developing a social living, religion, and society's values. In Islamic Law, in utilizing the waqf, the origin should not be reduced or damaged, the actual matter that given in waqf is its benefits, and the ownership of the waqf s assets is not devolved to nāzir, but only given to him to manage and control it following the intention of the wäqif (Sesse, 2010).

According to article 68 of Foundation Law, after the management and settlement of a foundation's wealth, if there is anything categorized as waqf assets, the assets will be transferred to the other foundation with similar activities or purposes or transferred to another legal entity. According to Foundation Law, the assets will be transferred to the state if the assets are not assigned to other foundations. It means that the foundation's wealth is purely intended for the foundation's activities, which are social, religious, and humanitarian purposes.

\section{Conclusion}

The BankruptcyAct's ambiguity in determining bankruptcy assets creates a contradiction to other laws such as Waqf Act and Foundation Act that confuse law enforcers, mostly curators, who manage the debtors' assets during the bankruptcy process. Curator and the Supervisory Judges play an essential role in managing and settling the bankrupt debtor, especially in classifying and inventorying the bankrupt assets. Implementing its functions, the curator should pay attention to other laws. If curator and supervisory judges only refer to the Bankruptcy Law, there is no acknowledgment of waqf or bankrupt assets limitation in it. As the ones who have authority, curators should pay attention to other regulations. It means that the code should be linked with the legal regulations or other laws or with the whole legal system as one regulatory system.

In case the foundation that managed waqf assets is bankrupt, the waqf law will override the Bankruptcy Law. The waqf assets on a bankrupt foundation can not be categorized as bankrupt assets. Based on this problem, the author suggests to issued Supreme Regulation about the limitation of bankruptcy assets, particularly emphasizing that waqf assets cannot become bankruptcy assets. It will stand as 


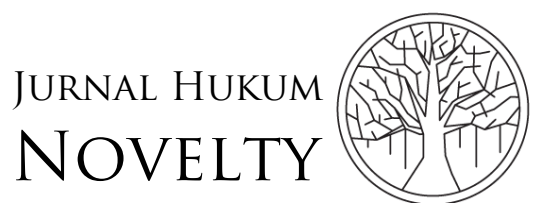

Volume 12, Issue 01, 2021, pp. 45-53

P-ISSN: $1412-6834$

E-ISSN: 2550-0090

guidance and become a legal basis for the curator to implement its functions to prevent the curator from being misled in determining the bankrupt assets.

Based on Foundation Act, the foundation that disbanded and still has the remaining wealth, the rest of its wealth does not return to the donator (wāqif). It will be left to another foundation with the same purpose or transferred to the state with appropriate use with the foundation's objectives and purpose. In the author's perspective on these problems, Foundation Act needs a clear provision about the dissolution of foundation which is the Foundation automatically disbanded after the bankruptcy. Secondly, the management of the waqf assets or other assets under the Foundation Act leads to the possibility of a legal entity that not following the purposes of the foundation. In this matter, it may be misused to be profit-oriented even though both conduct the same activities. In the author's perspective, the term of legal entity should be emphasized to cover the misleading utilization of the waqf assets when it is transferred.

\section{References}

Anugrah, Dian., \& Aswaritka, Listya. (2018). Kedudukan Yayasan yang belum disesuaikan dengan Undang-Undang Yayasan Setelah Jangka Waktu Berakhir, Notaire, Vol. 1 No. 1, 86-104.

Arkisman. (2015). Pelaksanaan Tugas Kurator dalam Mengurus Harta Pailit Berdasarkan Pasal 72 Undang-Undang No. 37 Tahun 2004 Tentang Kepailitan dan Penundaan Kewajiban Pembayaran Utang. Jurnal Pro Hukum, 7-12.

Hafiidh, M., \& Adjie, H. (2011). Yayasan: Memahami Pendirian-PerubahanPembubaran Yayasan Sebelum dan Sesudah Berlakunya Undang - Undang Nomor 16 Tahun 2001 tentang Yayasan. Bandung: PT Citra Aditya Bakti.

Hazami, B. (2016). Peran dan Aplikasi Wakaf dalam Mewujudkan Kesejahteraan Umat di Indonesia. Analisis Jurnal Studi Islam, 185-190. doi:https://doi.org/10.24042/ajsk.v16i1.742.

Hudayanti, N. (2017). Distribusi Aset dan Kekayaan Yayasan: Perspektif Perundang-undangan. Al-daulah Jurnal Hukum Pidana \& Ketatanegaraan, 207-210. Retrieved from http://journal.uinalauddin.ac.id/index.php/al_daulah/article/view/4877

Meliala, Eddy Putra., Siregar, Ramli., Windha. (2013). Pertanggungjawaban Pengurus Yayasan Terhadap Pailitnta Yayasan Menurut. Economic Journal "TRANSPARENCY", 2-10.

Murni, \& Gani, A. (2020, January 1). Tanggung Jawab Hukum Kepada Pengurus Yayasan Terhadap Failednya Suatu Yayasan. Jurnal Pionir LPPM Universitas Asahan Vol, Vol. 6 No. 1, 41-42. Retrieved from http://jurnal.una.ac.id/index.php/pionir/article/view/1057

Nasution, B., Windha, \& Sitorus, D. C. (2013). Prinsip Akuntabilitas dan Transparansi Yayasan dalam Rangka mencegah praktik Pencucian Uang (Money Laundering). Transparency Journal of Economic Law, Vol.1 No.1. Retrieved 
from https://www.neliti.com/publications/14687/prinsip-akuntabilitasdan-transparansi-yayasan-dalam-rangka-mencegah-praktik-pen

Nurhidayani, Muaidy Yasin, Busaini. (2017). Pengelolaan dan Pemanfaatan Wakaf Tanah dan Bangunan. Jurnal Kajian Ekonomi Islam, 1 -14.

Pratama, B. (2014). Kepailitan dalam Putusan Hakim Ditinjau Dari Perspektif Hukum Formil dan Materil. Jurnal Yudisial, 157-159. Retrieved from https://jurnal.komisiyudisial.go.id/index.php/jy/article/view/85

Retnaningsih, S. (2017, Januari-Juni). Perlindungan Hukum Terhadap Debitor Pailit Individu dalam Penyelesaian Perkara Kepailitan di Indonesia. ADHAPER: Jurnal Hukum Acara Perdata, Vol 3, No 1, 1-16. Retrieved from https://jhaper.org/index.php/JHAPER/article/view/41

Rukmono, B. S. (2019). The Role of Supervisory Judge Inresolving the Deadlock of the Assets Settlement in Bankruptcy of Foundation. Yustisia Jurnal Hukum, 72-75. Retrieved from https://jurnal.uns.ac.id/yustisia/article/view/28000

Sahupala, M. (2016, Januari). Tugas dan Wewenang Hakim Pengawas Terhadap Pengurusan dan Pemberesan Harta Debitor Pailit. Lex Privatum, Vol.4 No.1., 57-65. Retrieved from https://ejournal.unsrat.ac.id/index.php/lexprivatum/article/view/11165

Santoso, U. (2014). Kepastian Hukum Wakaf Tanah Hak Milik. Perspektif, 71-80.

Sesse, M. S. (2010). Wakaf Dalam Perspektif Fikhi Dan Hukum Nasional. Jurnal Hukum Diktum, 143-160.

Simamora, Y. S. (2012). Karakteristik, Pengelolaan dan Pemeriksaan Badan Hukum Yayasan di Indonesia. Jurnal Rechtsvinding, 175-186.

Sinaga, N. A., \& Sulisrudatin, N. (2016). Hukum Kepailitan dan Permasalahannya di Indonesia. Jurnal Ilmiah Hukum Dirgantara, Volume 7 No. 1, 168-170. Retrieved from http://garuda.ristekbrin.go.id/journal/view/14963?issue=\%20Vol\%207,\% 20No\%201\%20(2016):\%20JURNAL\%20ILMIAH\%20HUKUM\%20DIRGANT ARA

Sjahdeini, S. R. (2018). Sejarah, Asas, dan Teori Hukum Kepailitan : Memahami UndangUndang No. 37 Tahun 2004 tentang Kepailitan dan Penundaan Kewajiban Pembayaran Utang. Jakarta: Prenadamedia Group.

Sutrisno. (2017). Pemberdayaan Tanah Wakaf yang Dikelola Yayasan. Jurnal Pembaharuan Hukum, 140-146.

Wijayanta, T. (2014). Kajian Tentang Pengaturan Syarat Kepailitan Menurut Undangundang No. 37 Tahun 2004. Mimbar Hukum, Vol. 26, No. 1., 2-4. 